\title{
Analysis of Destination Image, Tourism Object, and Infrastructure Effect on Tourism Visiting Intention to Wamena (A Case Study of Tourism Development Planning in Wamena)
}

\author{
Tine Yuliantini Deden Kurniawan Dadan Ramdani \\ Management Department, Business and Economy Faculty \\ Universitas Mercu Buana
}

\begin{abstract}
Wamena as one of the National Tourism Destinations (DPN) has high tourism potential, consequently it can be a locomotive for economic growth in Papua. However, Wamena still has struggled with infrastructure and it has to be prompted by creating destination image. This study is conducted to analyse tourists' intention effect to visit Wamena. Sampling method used is random sampling through questionnaires and it is analyzed by using Partial Least Square. The results of data processing confirms that destinationi mage and tourism object have positive and significant effect on visiting intention, while infrastructure has negative and insignificant effect on tourism visiting intention to Wamena. Inadequate infrastructure is not a barrier for tourists to visit it. Beautiful scenery and fascinating destination objects are elementary generator for them to visit it. Thereby, tourism development can be implemented in Wamena as mountain or adventure tourism working with great physical. Approach should be committed by government or privates to cultivate potential tourism in Wamena through exposing its authentic culture and destination objects to promote best image destination.
\end{abstract}

Keywords: destination image, tourism object, infrastructure, visiting intentions, Wamena

DOI: $10.7176 / \mathrm{JMCR} / 59-06$

Publication date: August $31^{\text {st }} 2019$

\section{INTRODUCTION}

Marketing management relates to how entire of marketing communication activities are doable maximally in catching up customers and they used for selling product (Bungin, 2015). A destination image aims to promote tourism destination products in order to competitive in tourism market. This market is committed since tourism plays important role and contribution for national economy through state foreign exchange income shared by foreign tourists. Considering Indonesia has a variety of culture and abundant natural resources, the tourism sector can be optimized to contribute to the national economy (Astini and Sulistiyowati, 2015)

Data and Information Center of Tourism Ministry (2016) released that tourism was the fourth highest sector contributed to national economy, 11.629,9 million US\$, and it is stated on Table 1.1. Moreover, tourism is under other sectors as oil, gas, coal, palm oil. This sector regularly has increased contributing on national economy, while the other sectors tend to less in contribution. It can be concluded that tourism potency has not been optimized yet in marketing, subsequently its contribution for national economy is under other sectors.

Table 1.1 Tourism Contribution on Indonesian Economy (in million US\$)

\begin{tabular}{|l|l|l|l|l|}
\hline No & Komoditi & $\mathbf{2 0 1 3}$ & $\mathbf{2 0 1 4}$ & $\mathbf{2 0 1 5}$ \\
\hline $\mathbf{1}$ & Oil and Gas & 32.633 & 30.318 & 18.906 \\
\hline $\mathbf{2}$ & Coal & 24.501 & 20.819 & 16.359 \\
\hline $\mathbf{3}$ & Palm Oil & 15.839 & 17.646 & 15.485 \\
\hline $\mathbf{4}$ & Tourism & 10.054 & 11.166 & 11.629 \\
\hline $\mathbf{5}$ & Synthetic rubber & 9.316 & 7.450 & 7.340 \\
\hline
\end{tabular}

Source: Data and Information Center of Tourism Ministry (2016)

The data signifies that tourism is always consistent contributing on state foreign exchange. The consistency is impact onnumber of foreign tourists visitingIndonesia are going up. Domestic tourism increases every yearas well. Measurement method used to identify tourism visiting statistic can be seen by number of passengers in particular transportation mode, retribution to tourism destination, visitor of hotel, restaurant, and population census. The increment of tourists visiting number can be discerned on Table 1.2 below.

Table 1.2 Number of Tourist in Indonesia

\begin{tabular}{|l|l|l|l|}
\hline Tourist & $\mathbf{2 0 1 5}$ & $\mathbf{2 0 1 6}$ & $\mathbf{2 0 1 7}$ \\
\hline Domestic & 256 & 264 & 270 \\
\hline Foreign & 10 & 11 & 14 \\
\hline
\end{tabular}

Annotation: Number in Million

Source: Ministry of Tourism (2018)

One of the attempt to generate tourist visiting is by promotion and it is manifested by Indonesian government through creating an image and slogan, Wonderfull Indonesia. Image in marketing communication is 
strategic process to grow up long term vision and representable the place then appeal tourist intention to visit (Lubis, 2018). One of the image function is identity sharing of product and to make it true needs awareness to the image (Fill, 2013 in Bungin, 2015).

Easy access is one of the factors predispose to get to tourism destination. It plays much role to get to tourism object and facilitates tourists are going to visit the object (Astiti, 2018). Nowadays, Indonesia has regulated easy access policies for foreign tourists visiting Indonesian areasthrough three entrance lines, are land, sea, and air. In addition, mechanism has been agreed is by Visa On Arrival (VOA), Clearance and Approval for Indonesian Territory (CAIT), Flight Diplomatic Clearance (FDC), and Free Visit Visa. On the other hand, to boost up domestic tourist visiting, government provides additional routes which are directly going to tourism destination.

Government as regulator has decided tourism management policy by Law Number 10 of 2009 about Tourism (Law No.10/2009) and it aims to enhance economy and prosperity growth, cut off poverty, eliminate jobless, preserve nature and environment, promote culture, elevate nation image, embed loving for homeland, strengthen country identity and unity, and tighten transnational brotherhood.

To fasten tourism development, government has released Government Regulation number 50 of 2011 about Master Plan of National Tourism Development (RIPPARNAS) 2010-2025 (PP No.50/2011) as attempt to refine Indonesian tourism destination quality and quantity, effectively, efficiently, and responsible communicate it through marketing media, create tourism industry which moveable national economy and raise up tourism institution and governance professionally, effectively, and efficiently synergizing it to tourism destination, marketing, and industry. By dividing National Tourism Destination (DPN) into some areasare expected to have structure and integration between central and local government.

In DPN area division, Wamena is part of Sentani-Wamena. This division shares opportunity to embody wealthy natural resource, fascinatingnature and culture tourism to explore. It aims to lift up tourist visiting number and then it predisposes economy growth and people quality life for refinement.

Wamena geographically is inland area and it has to be followed by social infrastructure development to get to such as airport, road, hotel, transportation, energy, craft and other industries concerning to tourism from upstream to downstream. They are needed by tourists to get to and stay during tourism destination, consequently tourists are cozy and share multiplier effect for people prosperity.

Adequate infrastructure is one of the requirement to develop tourism. It is not only to drive economy growth, and retain competitiveness, but also it supports minimizing poverty and jobless (Kementerian Perhubungan, 2018). However, infrastructure in Indonesia is still the lowest one compared to the other develop countries. This is being issue and predisposing foreign tourists visiting number (Sri, 2013 in Sabon, Perdana, Koropit, and Pierre, 2018). Wealthy natural resource cannot be optimized since supporting tourism infrastructure still has trouble and it predisposes tourism destination image.

One of the action taken by government to build infrastructure in Wamena is by creating tourism destination image. The feasible infrastructure development project committed to elevate tourism image is by opening road access or Trans-Papua as it simplifies access for both foreign and local tourists to get to the tourism destination object. Additionally, the government should be serious to expose isolated area in inland Papua. The urgency of transportation for nation life is as development supporting for other sectors and exposing isolation among areas, in Wamena it is being issues and restrain tourism development.

Trans-Papua is $4.300 \mathrm{~km}$ from Papua to Papua Barat province and it is started from Jayapura through Sorong. It has supported tourism activities and minimized distribution cost for goods and services (Kementerian Pekerjaan Umum dan Perumahan Rakyat, 2017). Based on the empirical data through expedition done by Ring of Fire Adventure team confirms that Trans-Papua lane is available and it is accessible although its condition is incompletely proper to pass through. The condition is caused by tough area and goods distribution are difficult and expensive. In addition, the expedition verifies that Trans-Papua has connected. However, particular lane, from Tiom to Enarotali in Pegunungan Tengah area have not accessible yet through land line since security reason.

The other supporting facilities like hotel/resort and restaurant/food stall plays important role to support tourists' comfort. Accommodation completeness in Wamena has to be refined in supporting tourism development.

The other issues being inhibitor for tourism growing up in Wamena are much cost has to spend going to target destination. It affects on number of tourists visiting Wamena. Number of tourists visiting Wamena from 2015 to 2017 has decreased. However, domestic tourists has increased from 2015 to 2017. Those number are the lowest one, $0,001 \%$ if compared to entire tourist visiting Indonesia. The following table is number of tourists visiting Wamena. 
Table 1.4Number of Tourist Visiting Wamena

\begin{tabular}{|c|r|r|}
\hline Year & \multicolumn{2}{|c|}{ Tourist } \\
\hline & \multicolumn{1}{|c|}{ Foreign } & \multicolumn{1}{c|}{ Domestic } \\
\hline 2015 & 1.232 & 31.450 \\
\hline 2016 & 1214 & 41.489 \\
\hline 2017 & 938 & 47.804 \\
\hline
\end{tabular}

Source: Central Bureau of Statistics (2018)

Destination image is one of the important factors affect tourist visiting to a destination. Sunaryo (2013) proposed that image of a destination has positioning, is to embed an image in market (tourist) through integrated design among product quality, marketing communication, price policy, marketing line are going to develop and feasible expression of a product.

It is a representativedestination tourism overviewpredisposingtourist's decision to visit. It can be seen through tourism object. Irawan (2010) stated that tourism object is a characteristic owned by object as uniqueness, originality or rarity and then driving tourist's motivation and value.

To create well destination image, it has to portray comfortable destination for tourists when they visit. One of the element within it is adequate infrastructure and it is entire facilities for public (tourists) which allowing them easy and comfortable if they stay or visit a destination (Yoeti, 2010).

Based on the phenomena and relevant studies in advance, this study would scrutinize factors affecting tourist visiting intention. This study therefore is under tittle "ANALYSIS OF DESTINATION IMAGE, TOURISM OBJECT, AND INFRASTRUCTURE EFFECT ON TOURISM VISITING INTENTION TO WAMENA" (Case Study in Tourism Development Planning in Wamena)

Objective

This study aims to confirm variables have effect on tourism visiting intention. Completely, the objectives of this study can be stated below:

1. To know the effect of destination image on tourism visiting intention to Wamena.

2. To know the effect of tourism object on tourism visiting intention to Wamena.

3. To know the effect of infrastructure on tourism visiting intention to Wamena.

\section{LITERATURE REVIEW AND HYPOTHESIS}

\section{Tourism Management}

\section{Destination Image}

Pitana and Diarta (2009) figured out that image is tourists' trust regarding to product or service (will) purchased by them. That is in line with Sapta Pesona's point is memory. Tourists will always remember destination they visit because destination image impression. It has impact on destination marketing through memorable impression then tourists will recommend it to candidate tourists to visit it.

They recommend it as they have experienced in the destination and they assess it. Coban (2012) in Hanif, Kusumawati, Mawardi (2016) in their study reported that destination image is comprised of the result of rational study or cognitive image and emotional assessment or affective image of the destination. On the other hand, cognitive image is somebody's belief and information concerning to a destination. Whereas, affective image according to Artuğer, Cetinsoz, Kilic (2013) is somebody's emotion or feeling overview in term of a destination.

\section{Tourism Object}

Irawan (2010) implied that tourism object is an object characteristic as uniqueness, originality or rarity driving tourist's motivation and value. An interesting place or nature state is absolutely enjoyed by tourist in general. The potential and fascinated tourism object regularly have to build up, then it is being competitive and tourists are satisfied to the object they visit.

Tourism object is one of the important element in tourism field. It may support government program to preserve nation custom and culture as sellable asset to tourists. Tourism object as nature, culture life order, and soon has allure and selling value for tourists to visit. In broad sense, everything has tourism attraction or captivate tourists may be called as tourism object (Sinaga, 2010).

According to Yoeti (2010) tourism object has some kinds and they may predisposetourists to visit a destination and they are:

1. Agrotourism

2. Culture Tourism

3. Adventure Tourism

4. Culinary Tourism

5. Mountain Tourism 
Infrastructure

Yoeti (2010) defined infrastructureas entire facilities for public (included tourist) which allowing people get easiness, comfort, for some water supply, waste drainage system, oil, communication system, drainage system, construction, (road, path, parking lot, garden, lighting in the night, airport line, marine, port facilities, bus, train station, and tourism installation service. The supporting infrastructure is needed for tourists' comfort when they have tour travel.

Yoeti (1990) in Darwis, Hendraningrum, Adriani (2017) claimed that thoroughly tourism facilities allow tourism alive, grow up, and serve tourists multiform needs.

Framework of Thinking

The following figure is pointing out framework of thinking of this study.

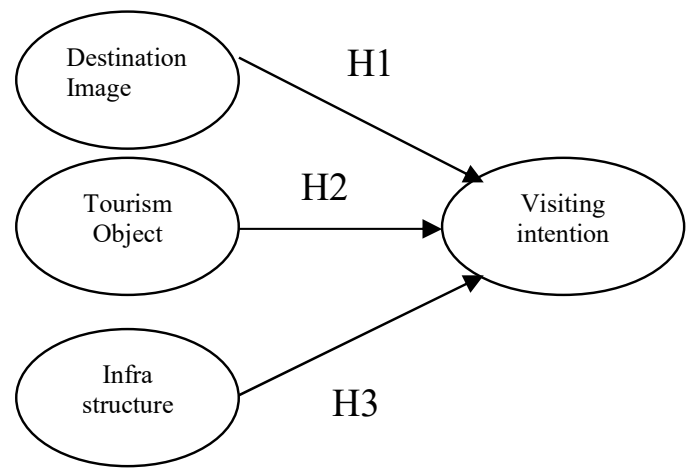

Figure 2.1 Framework of Thinking

\section{Hypothesis}

H1: destination Image has effect on visiting intention

$\mathrm{H} 2$ : Tourism Object has effect on visiting intention

H3: Infrastructurehas effect on visiting intention

\section{METHODOLOGY}

\section{Population and Sample}

The taken population of this study aretourists who visited since 2011, 5.105tourists (BPS, 2018). Due to cost and time to get to all of the tourists, then number of samples taken are in line with Hair's (2011) statement and he said that minimum representative sampling is due to number of indicator multiplied five to ten.

This study takes 147 samples to get more representative data. Sampling technique used is Random sampling by criteria both domestic and foreign tourists who have intention to visit Wamena.

\section{RESULT AND DISCUSSION}

\section{Evaluation for Measurement Model (Outer Model)Test}

a.Validity Test

Validity test works to know instrument capability quantifying what should be measured.

1) Convergent Validity

Convergent validity of each construct indicator is counted by PLS (Partial Least Square). According to Ghozali (2014), an indicator is stated valid if it has good valid and more than 0,70, while sufficient considered loading factorvalue is 0,50 to 0,60 . Based on this criteria, loading factorvalue is under 0,50 , then it will be dropped out from model. 


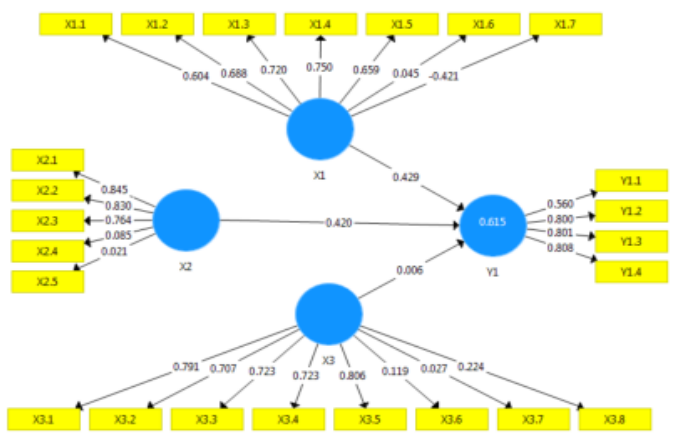

Figure 3.1 Initiation Iteration

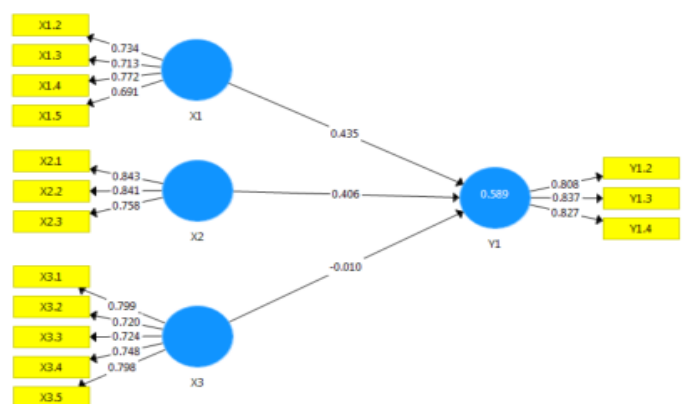

Figure 3.2 Last Iteration

Table 4.1 The Result of Convergent Validity (Outer Loading) Test

\begin{tabular}{|c|c|c|c|}
\hline Variable & Indicator & $\begin{array}{c}\text { Initiation } \\
\text { Iteration }\end{array}$ & $\begin{array}{c}\text { Last } \\
\text { Iteration }\end{array}$ \\
\hline \multirow{4}{*}{$\mathbf{X}_{1}$} & $\mathrm{X}_{1.1}$ & 0,604 & \\
\cline { 2 - 4 } & $\mathrm{X}_{1.2}$ & 0,688 & 0,734 \\
\cline { 2 - 4 } & $\mathrm{X}_{1.3}$ & 0,720 & 0,713 \\
\cline { 2 - 4 } & $\mathrm{X}_{1.4}$ & 0,750 & 0,772 \\
\cline { 2 - 4 } & $\mathrm{X}_{1.5}$ & 0,659 & 0,691 \\
\cline { 2 - 4 } & $\mathrm{X}_{1.6}$ & 0,045 & \\
\cline { 2 - 4 } & $\mathrm{X}_{1.7}$ & $-0,421$ & \\
\hline \multirow{4}{*}{$\mathbf{X}_{\mathbf{4}}$} & $\mathrm{X}_{2.1}$ & 0,845 & 0,843 \\
\cline { 2 - 4 } & $\mathrm{X}_{2.2}$ & 0,830 & 0,841 \\
\cline { 2 - 4 } & $\mathrm{X}_{2.3}$ & 0,764 & 0,758 \\
\cline { 2 - 4 } & $\mathrm{X}_{2.4}$ & 0,085 & \\
\cline { 2 - 4 } & $\mathrm{X}_{2.5}$ & 0,021 & \\
\hline \multirow{4}{*}{$\mathbf{X}_{3}$} & $\mathrm{X}_{3.1}$ & 0,791 & 0,799 \\
\cline { 2 - 4 } & $\mathrm{X}_{3.2}$ & 0,707 & 0,720 \\
\cline { 2 - 4 } & $\mathrm{X}_{3.3}$ & 0,723 & 0,724 \\
\cline { 2 - 4 } & $\mathrm{X}_{3.4}$ & 0,723 & 0,748 \\
\cline { 2 - 4 } & $\mathrm{X}_{3.5}$ & 0,806 & 0,798 \\
\cline { 2 - 4 } & $\mathrm{X}_{3.6}$ & 0,119 & \\
\cline { 2 - 4 } & $\mathrm{X}_{3.7}$ & 0,027 & \\
\cline { 2 - 4 } & $\mathrm{X}_{3.8}$ & 0,224 & \\
\hline \multirow{4}{*}{$\mathbf{Y}$} & $\mathrm{Y}_{1.1}$ & 0,560 & \\
\cline { 2 - 4 } & $\mathrm{Y}_{1.2}$ & 0,800 & 0,808 \\
\cline { 2 - 4 } & $\mathrm{Y}_{1.3}$ & 0,801 & 0,837 \\
\cline { 2 - 4 } & $\mathrm{Y}_{1.4}$ & 0,808 & 0,827 \\
\hline
\end{tabular}

Source: Smart-PLS 3.0

Referring to the initiation iteration result, it can be obtained that $\mathrm{X}_{1.6}, \mathrm{X}_{1.7}, \mathrm{X}_{2.4}, \mathrm{X}_{2.5}, \mathrm{X}_{3.6}, \mathrm{X}_{3.7}$, and $\mathrm{X}_{3.8}$ indicators haveloading factorunder 0,50 , then it has to be dropped out from model as they are invalid. After modifying the model then last iteration result signify whole of indicators have loading factor value more than 0,50 . In consequence, it can be stated that those indicators are valid (significant). 


\section{2) Discriminant Validity}

Due to convergent validityis valid then the next test committed is disciminant validity. In this section, reflective indicators may be discerned on cross loadingbetween indicators and their constructs. An indicator is stated valid if it has loading factor to other construct. Thereby, latent constructs predict indicator on their better block than the other ones.

Table 4.2 The Result of Discriminant Validity (Cross Loading) Test

Source: Smart-PLS 3.0

\begin{tabular}{|c|c|c|c|c|}
\hline & $\mathbf{X 1}$ & $\mathbf{X 2}$ & $\mathbf{X 3}$ & $\mathbf{Y}$ \\
\hline $\mathrm{X}_{1.2}$ & 0,734 & 0,510 & 0,336 & 0,544 \\
\hline $\mathrm{X}_{1.3}$ & 0,713 & 0,526 & 0,436 & 0,614 \\
\hline $\mathrm{X}_{1.4}$ & 0,772 & 0,550 & 0,552 & 0,450 \\
\hline $\mathrm{X}_{1.5}$ & 0,691 & 0,415 & 0,647 & 0,406 \\
\hline $\mathrm{X}_{2.1}$ & 0,586 & 0,843 & 0,510 & 0,575 \\
\hline $\mathrm{X}_{2.2}$ & 0,584 & 0,841 & 0,479 & 0,620 \\
\hline $\mathrm{X}_{2.3}$ & 0,523 & 0,758 & 0,385 & 0,516 \\
\hline $\mathrm{X}_{3.1}$ & 0,522 & 0,502 & 0,799 & 0,414 \\
\hline $\mathrm{X}_{3.2}$ & 0,480 & 0,372 & 0,720 & 0,338 \\
\hline $\mathrm{X}_{3.3}$ & 0,512 & 0,414 & 0,724 & 0,371 \\
\hline $\mathrm{X}_{3.4}$ & 0,461 & 0,353 & 0,748 & 0,377 \\
\hline $\mathrm{X}_{3.5}$ & 0,516 & 0,487 & 0,798 & 0,409 \\
\hline $\mathrm{Y}_{1.2}$ & 0,569 & 0,613 & 0,414 & 0,808 \\
\hline $\mathrm{Y}_{1.3}$ & 0,582 & 0,522 & 0,369 & 0,837 \\
\hline $\mathrm{Y}_{1.4}$ & 0,603 & 0,596 & 0,461 & 0,827 \\
\hline
\end{tabular}

On the Table 4.2, it is portrayed that tourists demand visiting Wamena are highly predisposed by clean environment and it is pointed by 0,772 . The tourism object immensely predispose tourists to visit Wamena, isFestival Lembah Baliem hosted every year and it displays native tribe mummy hundred years ago. It is pointed by 0,843 . Transportation availability is 0,799 .

\section{Table 4.3The Result of Discriminant Validity (Fornell Larcker) Test}

Source: Smart-PLS 3.0

\begin{tabular}{|c|c|c|c|c|}
\hline & $\mathrm{X}_{1}$ & $\mathrm{X}_{2}$ & $\mathrm{X}_{3}$ & $\mathrm{Y}$ \\
\hline $\mathrm{X}_{1}$ & 0,728 & & & \\
\hline $\mathrm{X}_{2}$ & 0,694 & 0,815 & & \\
\hline $\mathrm{X}_{3}$ & 0,657 & 0,565 & 0,759 & \\
\hline $\mathrm{Y}$ & 0,710 & 0,702 & 0,505 & 0,824 \\
\hline
\end{tabular}

From the Table 4.3, it is exposed that some of loading factorvalues for each latent variable indicators are lower than loading value if connected to the other ones. It indicates that each latent variable has good discriminat validityand some of them have high correlation gauge to the other constructs.

Table 4.4The Result of Average Variance Extracted(AVE) Test

\begin{tabular}{|c|c|}
\hline Variable & Average Variance Extracted (AVE) \\
\hline $\mathrm{X}_{1}$ & 0,530 \\
\hline $\mathrm{X}_{2}$ & 0,664 \\
\hline $\mathrm{X}_{3}$ & 0,576 \\
\hline $\mathrm{Y}$ & 0,679 \\
\hline
\end{tabular}

Source: Smart-PLS 3.0

Based on the Table 4.4, it can be concluded that Average Variance Extracted(AVE) square root of each construct is higher than correlation between one construct to the others in model, then estimated value satisfies discriminant validity.

b. Realibility Test

To ensure whether any problem or not concerning to measurement, then it takes last step of outer model evaluationis examining model reliability test. It is committed by using Composite Reliabilitty andCronbach's Alpha indicators.

Composite Reliability andCronbach's Alphaworks to test instrument reliability of research model or quantify internal consistencyand the value must be more than 0,60 . If entire of latent variables ofComposite Reliabilityor Cronbach's Alpha is $\geq 0,70$ then it means reliability construct is good or the used questionnaire as instrument of the research is reliable or consistent.

Table 4.5The Result5485 


6f Composite Reliability and Cronbach's Alpha Test
\begin{tabular}{|c|c|c|}
\hline 4 & Cronbach's Alpha & Composite Reliability \\
\hline $\mathrm{X}_{1}$ & 0,709 & 0,818 \\
\hline $\mathrm{X}_{2}$ & 0,747 & 0,856 \\
\hline $\mathrm{X}_{3}$ & 0,815 & 0,871 \\
\hline $\mathrm{Y}$ & 0,763 & 0,864 \\
\hline
\end{tabular}

Source: Smart-PLS 3.0

On the Table 4.5, it signifies that the result composite reliability andcronbach's alphatest have satisfied value, whole of latent variables are reliable since they are $\geq 0,70$. It can be inferred that the applied questionnaires in this study are consistent.

\section{Evaluation for Structural Model (Inner Model) Test}

a. Nilai $R$-Square

$\mathrm{R}$-square(R2) or determination coefficient value is 0,589 . It indicates $58,9 \%$ variation or visiting intention is affected by destination image, tourism object, and infrastructure, while the rest, $41,1 \%$ is elaborated by other factors outside of this study.

b. Goodness of Fit Model

Goodness of Fit Structural Modeltest on inner modeluses predictive relevance(Q2) value. Q-Squarevalue is higher than 0 (zero) representing that model has predictive relevance value. R-squarevalue of each endogenous variable of this study can be discerned on predictive relevance value by the following equation:

$\mathrm{Q} 2=1-(1-\mathrm{R} 2)$

$\mathrm{Q} 2=1-(1-0,589)$

$\mathrm{Q} 2=1-0,411$

$\mathrm{Q} 2=0,589$

The count result exposes predictive relevance value, $0,589 \geq 0$. It means that $58,9 \%$ of visiting intention variable (dependent variable) is described by variables used. The model therefore can be claimed fit for having relevant predictive value.

c. Hypothesis Test

The estimated value for path correlation in structural model must be significant. This significance value can be obtained by bootstrapping procedure. Considering the significance on hypothesis for parameter coefficient and $\mathrm{T}$-statistics significance value are on algorithm bootstrapping report. To ensure whether significant or not, it can be discerned on T-table of alpha $0,05(5 \%)=1,96$. After that, T-tableis compared to T-count (T-statistic).

Table 4.6The Result of Hypothesis Test

\begin{tabular}{|c|c|c|}
\hline & Original Sample (O) & T Statistics \\
\hline $\mathrm{X} 1$-> Y & 0,435 & 4,747 \\
\hline $\mathrm{X} 2$-> Y & 0,406 & 3,672 \\
\hline $\mathrm{X} 3$-> Y & $-0,010$ & 0,116 \\
\hline
\end{tabular}

Source: Smart-PLS 3.0

Based on the Table 4.7, it is elucidated some points as follows:

1. Destination Image has positive and significant effect on visiting intention as T-statistic $>$ T-table $(4.747>$ 1.96), in consequence hypothesis is accepted and it means destination image becomes tourists reason to have visiting intention.

2. Tourism Object has positive and significant effect on visiting intention as T-statistic $>$ T-table $(3.672>1.96)$ subsequently, hypothesis is accepted and it means tourism object becomes tourists reason to have visiting intention.

3. Infrastructure has negative and insignificant effect on visiting intention as T-statistic $<\mathrm{T}$-table $(0.116<$ 1.96), thus hypotheis is rejected. However, if this study is conducted in other places and same variables then they are probability have significant effect.

The following is construct output result of Bootstraping test: 


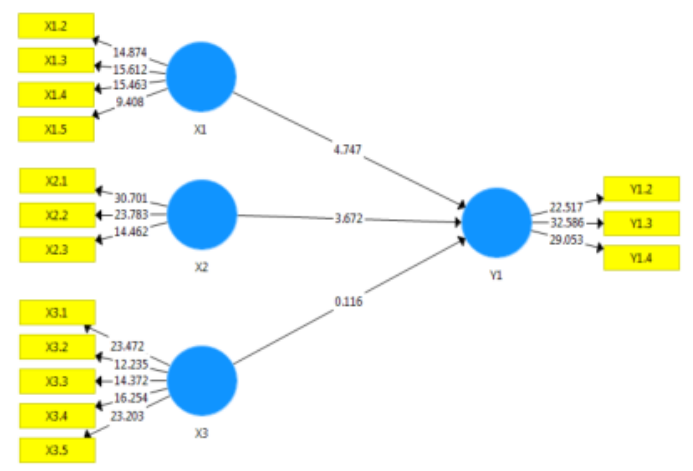

Figure 4.3 Bootstraping

\section{Discussion}

Based on the PLS (Partial Least Square) analysis result, then in this section it is discussed the result has been counted. This study aims to know destination image, tourism object, and infrastructure effect on visiting intention to Wamena. Tests are indicated by hypothesis allowing us to know how each variable predisposes on the other ones.

1. The effect of Destination Image on Visiting Intention

The first hypothesis (H1) elucidates that Destination Image has positive and significant effect on Visiting Intention. The positive path coefficient signifies in line correlation where the better destination image in Wamena then tourists visiting intention is getting higher. It confirms Putra'sand Pangestuti's (2018) study declared that destination image had significant effect on tourists' visiting intention. Good image forming is absolutely important for tourism development in Wamena, in consequence Wamena's existence as tourism destination will be better. It can be manifested through facilities service are needed by tourists during their visit. In addition, service quality refinement are urgent concerned for positive image in tourists' mind who will visit it.

2. The Effect of Tourism Object on Visiting Intention

The Second hypothesis (H2) discloses that Tourism Object has positive and significant effect on Visiting Intention. The positive path correlation portrays in line correlation where the most interesting of tourism object in Wamena then the tourists' intention to visit it is getting higher. This result strengthen Bachtiar's and Wibowo's (2016) study reported that tourism object had positive and significant effect on visiting intention. Additionally, this study affirms Irawan's (2010) argument that tourism object is a characteristic owned by an object as uniqueness, originality, and rarity driving motivation and value. Local culture, therefore is an object typical which becomes fascination for tourists to visit it. If a tourism object is more unique then tourists' intention to visit are getting higher. Tourism objects are owned by Wamena being main fascination for tourists to visit. One of the tourism attraction is Festival Lembah Baliem and it has hosted annual and it needs to be optimized to introduce more local culture and tourism objects in Wamena.

3. The Effect of Infrastructure on Visiting Intention

Based on the third hypothesis (H3) of this study figures out that infrastructure has negative and insignificant effect on visiting intention. It means that infrastructure quality in tourism destination does not have effect on visiting intention. Even though, infrastructure quality in Wamena recently is adequate, yet it does not relieve tourist's enthusiasm to visit. That is in line with Budhiarta's (2011) study announced that infrastructure is regardless by tourists.

\section{CONSCLUSION AND SUGGESTION}

\section{A. Conclusion}

This study aims to know destination image, tourism object, and infrastructure effect on visiting intention to Wamena. Based on the data analysis and discussion have been proposed, then it can be drawn conclusion as follows:

1. Destination image has positive and significant effect on visiting intention. It is important factor predisposing visiting intention. It can be deduced that destination image impacts on visiting intention. The more positive of destination image then the tourists' visiting intention to tourism destination is getting higher. Within this variable the highest index is tourists going to consider clean environment state and free from pollution. Consequently, they are comfort when visiting. Clean environment condition has effect on destination image. If the condition is always 3clean then it stimulates tourists' visiting intention to Wamena.

2. Tourism object has positive and significant effect on visiting intention. It is important factor predisposing tourists' visiting intention.It can be inferred that unique and fascinated tourism object will generate tourists' 
visiting intention to tourism destination. The more unique and fascinated tourism object then tourists' visiting intention to tourism destination is getting higher. The highest index in this variable is tourists are more interested to Wamena as it has culture tourism object like Festival Lembah Baliem. Wamena's custom and culture show is exposed during the festival and it lures tourists' intention. The festival is medium for Wamena to promote its much tourism potency owned.

3. Infrastructurehas negative and insignificant effect on visiting intention. It can be concluded that inadequate infrastructure availability does not effect on tourists' visiting intention to Wamena. The highest index in this variable is tourists prioritize easiness transportation to get to tourism destination, although they spent expensive cost.

\section{B. Suggestion}

Based on the result, discussion, and conclusion, then it can be suggested to any parties using this study's result for the future and the suggestions are stated below:

1. The proper tourism development in Wamena is mountain tourism. It is in line with Yoeti's (2010) argument claimed that the center of tourism mountain activity is run in beautiful view or rare plant, and they have affluent agricultural products. Colorful culture in Wamena can be explored further to have added value and allure then be able to compete globally. Adventure tourism is fit if implemented in Wamena area as it is nature activity compelling fine physical. Moreover, clean environment has to be preserved in destination tourism to serve tourists comfort.

2. To develop Tourism in Wamena due to it has potential tourism and affordable for globally tourists and it should be promoted concerning to colorful culture by showing originality of Wamena's culture as Festival Lembah Baliem show. This festival should be refined its organizing quality. Promotion has to be organized to create positive destination image then it predisposes tourists' visiting intention to Wamena.

3. Tourism potency in Wamenais inseparable from government institution or private. To develop it can be served by infrastructure, road, airport, resort, and restaurant or food stall as supporting facilities for tourists. Building and developing infrastructure will predispose tourists' intention to visit. Additionally, it is expected to pressure expenses to visit Wamena.

\section{BIBLIOGRAPHY}

Ali, F., Atmawidjaja, E.S., Novrianto, R\&Waluyo, D. 2017. Mengejar Ketertinggalan Infrastruktur(Ed). Jakarta: Kementerian Pekerjaan Umum dan Perumahan Rakyat RI.

Artuger, S., Cetinsoz, B.C.\&Kilic, I. (2013). The Effect of Destination Image on Destination Loyalty: An Application In Alanya. European Journal of Business and Management, 5 (13).

Astini, R dan Indah, S. (2015). Pengaruh Destinaion Image, Travel Motivation dan Kualitas Pelayanan terhadap Kepuasan Pengunjung (Studi Kasus pada Wisatawan Nusantara Muslim di Pantai Carita Pandeglang). Jurnal Ilmiah Manajemen dan Bisnis, 1 (3).

Bactiar, M.L dan Arif, W. (2016). Pengaruh Strategi Bauran Pemasaran Terhadap Minat Berkunjung Kembali Di Objek Wisata Pantai Kabupaten Gunung Kidul (Studi Pada Mahasiswa Strata 1 Fakultas Ekonomi Universitas Negeri Yogyakarta). Skripsi Fakultas Ekonomi Universitas Negeri Yogyakarta.

Budhiarta, R.M.N. 2011. Peranan Transportasi Dalam Pariwisata (Studi Kasus Pemilihan Daerah Tujuan Wisata (DTW/Destinasi) Oleh Wisatawan Di Bali). Jurnal Ilmiah Teknik Sipil, 15(02).

Bungin, B. 2015. Komunikasi Pariwisata (Tourism Communication): Pemasaran dan Brand Destinasi. Jakarta: Prenadamedia Group.

Darwis, R.H.R.A.\&Adriani, Y. 2016. Kelayakan Fasilitas Publik Dalam Kawasan Industri Wisata Belanja di Kota Bandung (Studi Kasus Terhadap Toilet dan Musola). Barista, 3(2).

Hanif, A.K\&Mawardi, M.K. 2016. Pengaruh Citra Destinasi Terhadap Kepuasan Wisatawan Serta Dampaknya Terhadap Loyalitas Wisatawan (Studi pada Wisatawan Nusantara yang Berkunjung ke Kota Batu. Jurnal Administrasi Bisnis, 38 (1).

Hair, J.F., et al. 2011. Multivariate data analysis. (7th edition). New Jersey: Pearson Education Inc.

Irawan, K. 2010. Potensi Objek Wisata Air Terjun Serdang Sebagai Daya Tarik Wisata Di Kabupaten Labuhan Batu Utara (Thesis).Program Pendidikan Non Gelar dalam Program Studi Pariwisata, Fakultas Sastra, Universitas Sumatera Utara.

Pitana, I.G.\&Diarta, I.K.S. 2009. Pengantar Ilmu Pariwisata. Yogyakarta: CV. Andi Offset

Pusat Data dan Informasi. 2016. Jakarta: Kementerian Pariwisatta RI.

Putra, D.A\&Pangestuti E. 2018.Pengaruh City Branding “The Hearth Of East Java" Pada Minat Berkunjung dan Keputusan Berkunjung (Survei pada Wisatawan yang Berkunjung ke Kabupaten Malang). Jurnal Administrasi Bisnis, 61 (4).

Sabon, V., Lelu., et.al. 2018). Strategi Peningkatan Kinerja Sektor pariwisata Indonesia Pada Asean Economic Community. Jurnal Bisnis Manajemen,8(2). 
Sinaga, S. 2010. Potensi dan Pengembangan Objek Wisata Di Kabupaten Tapanuli Tengah (Thesis). Program Studi Pariwisata, Fakultas Sastra, Universitas Sumatera Utara.

Sugiyono. 2013. Metode Penelitian Bisnis. Bandung: Alfabeta.

Sunaryo, B. 2013. Kebijakan Pembangunan Destinasi Pariwisata: Konsep dan Aplikasinya Di Indonesia. Yogyakarta: Gava Media.

Yoeti, O.A. 2010. Dasar-Dasar Pengertian Hospitaliti dan Pariwisata. Bandung: PT. Alumni. 